\title{
Kierunki interpretacji motywu wampira w wybranych tekstach kultury od XIX do XXI wieku (rekonesans)
}

\author{
Directions in Interpretation of the Vampire Theme in Selected Texts of Culture \\ from the 19th to the 21st Century (Reconnaissance)
}

\begin{abstract}
The article aims at offering an overview of directions of interpretation regarding the motif of vampire in popular literature from the 19th to the 21 st century. It focuses on the most important, representative texts of culture that have had the greatest influence on the evolution of the vampire figure from Romanticism to the modern times, such as Dracula, Salem's Lot, Interview with the Vampire, Twilight. The article intends to present various ways of reading and analysing vampirism depending on different methodologies. Undoubtedly, the approaches regarding interpretations of films and literary works featuring vampires have been conditioned by exegetical possibilities brought about by the methodological development in literary and cultural studies.
\end{abstract}

Keywords: vampire, interpretation, text of culture, culture, literature, film

\begin{abstract}
Abstrakt: Artykuł ma na celu przedstawienie przeglądu kierunków interpretacji motywu wampira w kulturze popularnej od XIX do XXI wieku. Skupia się na najważniejszych, najbardziej reprezentatywnych tekstach, które wywarły największy wpływ na ewolucję postaci wampira od romantyzmu do czasów współczesnych, takich jak: Dracula, Miasteczko Salem, Wywiad $z$ wampirem, Zmierzch. Zamierzeniem było ukazanie różnych sposobów odczytywania i analizowania wampiryzmu w zależności od przyjętej metodologii. Niewątpliwie - tytułowe kierunki interpretacji utworów wampirycznych były warunkowane możliwościami egzegetycznymi, jakie niesie metodologiczny rozwój literaturoznawstwa i kulturoznawstwa.
\end{abstract}

Slowa kluczowe: wampir, interpretacja, tekst kultury, kultura, literatura, film 
„[...] bo nigdy dość się nie umiera..."

Bolesław Leśmian

\section{Wstępne rozpoznania}

Celem niniejszego przyczynku badawczego jest próba zarysowania kierunków interpretacji tekstów kultury, w tym przede wszystkim kultury popularnej XX i XXI wieku², w których wyraźnie został zaznaczony motyw wampiryczny. Omówienie zostanie zaprezentowane na przykładzie wybranych, najbardziej reprezentatywnych utworów literackich i filmowych, które miały największy wpływ na ewolucję figury wampira od czasów romantycznych do współczesnych. Nie chodzi jednak o same teksty, ale o sensy oraz znaczenia, które owe utwory tworzą na drodze różnorodnych zabiegów lekturowych. Niewątpliwie - tytułowe kierunki interpretacji utworów wampirycznych warunkowane były (i są) możliwościami egzegetycznymi, jakie niesie ze sobą nieustanny rozwój metodologii badań literackich oraz kulturowych.

Za punkt wyjścia należy uczynić słowa Marii Janion: „W historii wampirów odnajdujemy nas samych - patriarchalną rodzinę, mściwy patriotyzm, nasz stosunek do władzy"3. Przytoczony cytat tłumaczy popularność wampirów, która nie słabnie od ponad 250 lat, gdy pojawiły się po raz pierwszy w literaturze: w utworze Der Vampir Heinricha Augusta Ossenfeldera z 1748 roku, który można uznać za prekursorski ${ }^{4}$, a przede wszystkim w balladzie Narzeczona z Koryntu Johanna Wolfganga Goethego, napisanej w 1797 roku $^{5}$. Wampiryczne narracje są zwierciadłem ludzkich opowieści, jak zaznacza Janion: „, to jest jakby alternatywna historia ludzkości”' Wampir jest jednym z najsławniejszych bohaterów współczesnej kultury popularnej. Można zaryzykować twierdzenie, że nie istnieje lepiej rozpoznawalna figura artystyczna, dlatego podlega ona nieustannej eksploatacji; wciąż istnieje zapotrzebowanie na opowieści o wampirach. Wynika to $\mathrm{z}$ atrakcyjności tej figury, która opiera się na nierozerwalnym związku lęku i fascynacji.

B. Leśmian, Dziewczyna, [w:] idem, Poezje, oprac. J. Trznadel, Warszawa 1994, s. 249.

2 Na potrzeby niniejszego artykułu przyjmuję rozumienie kultury popularnej jako tej, której treści „są łatwe w odbiorze, często bardzo skonwencjonalizowane, oraz które zawierają wyraźne elementy rozrywkowe i tym samym przyciągają liczną publiczność”, M. Golka, Socjologia kultury, Warszawa 2007, s. 146.

3 Wampir jest $w$ każdym z nas. Profesor Maria Janion $w$ rozmowie z Piotrem Najsztubem, „Przekrój” 2003, nr 29, s. 60.

4 Zob. H. Crawford, The Cultural-Historical Origins of the Literary Vampire in Germany, „Journal of Dracula Studies” 2005, Vol. 7, s. 4-7, https://research.library.kutztown.edu/cgi/viewcontent. cgi?article=1040\&context=dracula-studies (dostęp: 30.01.2021).

5 J.W. Goethe, Narzeczona z Koryntu, przeł. S. Zarębski [w:] idem, Wybór poezji, oprac. Z. Ciechanowska, BN II 48, Wrocław 1968, s. 124-131. Ballada przedstawia historię pięknej dziewczyny, która żali się spotkanemu mężczyźnie, że kult bóstw pogańskich odchodzi w zapomnienie, a ona nie chce przyjąć obcego jej chrześcijaństwa. Dochodzi do zaręczyn, a kobieta okazuje się wampirzycą. Utwór Goethego uchodzi za pierwsze literackie przedstawienie wampiryzmu, zob. M. Janion, Wampir. Biografia symboliczna, Gdańsk 2008, s. 14-16.

6 Wampir jest w każym z nas..., op. cit., s. 63. 
Jednak owa atrakcyjność ewoluowała od utworów romantycznych do tekstów kultury popularnej XXI wieku.

\section{Słowiańska przeszłość i znaczenie romantyzmu}

Poczesne miejsce zajmuje krwiopijca w dwudziestowiecznych badaniach nad wyobraźnią, fantazją i marzeniem, inspirowanych freudowską psychoanalizą, będących swoistą prefiguracją późniejszych poetyk spod znaku gender czy queer. Niewątpliwie proweniencji tego stanu rzeczy należy upatrywać w wieku XIX, gdy romantyzm przezwycięża ludowe pojmowanie wampira jako bestii, którą należy zlikwidować, gdyż zagraża ludzkiemu życiu. Znaczący wpływ na wykreowanie wizerunku wampira w kulturze popularnej miało właśnie ludowe rozumienie demonicznej istotowości tych stworzeń z pogranicza życia oraz śmierci, będących poza życiem, ale też poza śmiercią; chociaż należy podkreślić, że kreacje literacko-filmowe powstawały w kontrze do folklorystycznych wyobrażeń krwiopijcy. Zmarli wstający nocą z grobu, pijący ludzką krew to źródło lęku ludów europejskich, szczególnie południowo-wschodnich. Zwłaszcza Słowianie obawiali się wampirów (upiorów). Przekonanie o wysysaniu krwi przez upiory ze śpiących ludzi było powszechne na zachodzie i południu dawnej Rzeczypospolitej $^{7}$. Nie tylko jednak Słowianie wierzyli w wampiry, pojawiają się one w większości mitologii świata ${ }^{8}$.

Od romantyzmu rozpoczyna się myślenie i pisanie o wampirze w kategoriach fantomowych, gdyż właśnie w tym okresie mają miejsce narodziny fantazmatów 9 . Pojawiła się filozofia, która niosła ze sobą nową percepcję śmierci, jak stwierdza Philippe Ariès: „W czasach nowożytnych to, co dotąd było w śmierci dalekie, zostało przybliżone i zaczęła ona fascynować" ${ }^{10}$. W romantyzmie powstały nowe teorie wyobraźni ${ }^{11}$. Wampir przestał być potworem budzącym jedynie lęk, dzięki antropologii romantycznej stał się nową jakością kulturową, jak zauważa Filip Mazurkiewicz: „gdyby nie było wampirów, romantycy musieliby je koniecznie wymyślić dla uzasadnienia swej epistemologii”"12.

Krwiopijca postrzegany jako fantazmat, ,derywat marzenia"13, konstrukt wyobraźni to perspektywa interpretacyjna szczególnie mocno manifestowana w pisarstwie Janion, będącej pionierką badań nad wampiryzmem w Polsce i autor-

\footnotetext{
7 Zob. A. Brückner, Mitologia slowiańska i polska, Warszawa 1980, s. 178; A. Gieysztor, Mitologia Stowian, Warszawa 1982, s. 222; K. Moszyński, Kultura ludowa Stowian, t. II, Kultura duchowa, cz. 1, Warszawa 1967, s. 628.

8 Zob. E. Petoia, Wampiry i wilkołaki. Źródła, historia, legendy od antyku do wspótczesności, przeł. B. Bielańska, J. Kornecka, N. Korzycka, M. Małecka, A. Pers, Kraków 2004.

9 Zob. M. Janion, Odnawianie znaczeń, Kraków 1980, s. 324.

10 P. Ariès, Człowiek i śmierć, przeł. E. Bąkowska, Warszawa 1992, s. 597.

1 Zob. M. Janion, Projekt krytyki fantazmatycznej. Szkice o egzystencjach ludzi i duchów, Warszawa 1991, s. 7.

12 F. Mazurkiewicz, Męskość dziewiętnastowieczna - prolegomena, „Teksty Drugie” 2015, nr 2, s. 44.

13 M. Janion, Projekt krytyki fantazmatycznej ..., op. cit., s. 12.
} 
ką monumentalnego Wampira. Biografii symbolicznej (pierwsze wydanie miało miejsce w 2003 roku). W jej rozpoznaniach ,[w]ampir jest figurą albo transgresji, czyli przekroczenia, albo eksploatacji. [...] Przekroczenia mają najczęściej charakter erotyczny, seksualny. Natomiast wyzysk, eksploatacja jest zjawiskiem raczej społecznym" ${ }^{14}$.

\section{W kręgu interpretacji hermeneutycznych i filozoficznych}

W klasycznej interpretacji wampiryzmu, którą można umiejscowić na pograniczu hermeneutyki filozoficznej, metafizyki i antropologii, należy przyjrzeć się statusowi krwiopijcy, który jest bytem o wyjątkowo tragicznym statusie ontologicznym. Wampir, czyli nieumarły, żywy trup - ten oksymoron zdaje się najlepiej charakteryzować jego nieprzynależność do żadnego ze światów. Zmarły wstający nocą z grobu, niemogący zaznać spokoju, zawieszony między niebem a ziemią, życiem a śmiercią, znajdujący się w stanie „wiecznej liminalności”"15. Arnold van Gennep stan liminalności przypisał rytuałowi okresu przejściowego ${ }^{16}$, jednak egzystencja wampira jest wiecznością, męką wieczności, zatem to, co dla człowieka stanowi moment przejściowy, dla wampira jest nieustającym momentem przejściowym, który może zakończyć jedynie rytuał unicestwienia. Wojciech Józef Burszta stwierdza: „wiemy doskonale, jak owo «przekleństwo» zawieszenia pomiędzy dwoma światami - żywych i zmarłych - wykorzystuje kino spod znaku horroru [...]. Osoby nie przyjęte do społeczności i te, które nie zostały z niej obrzędowo wyłączone, zawsze są wyjątkowo niebezpieczne dla żyjących, a ich wygląd napawa zgrozą" ${ }^{17}$. Brak przynależności do któregoś z boskich porządków i uświadomienie sobie tego faktu stanie się genezą metafizycznego bólu dwudziestowiecznych wampirów.

Najważniejsza powieść wampiryczna, czyli Dracula Brama Stokera z $1897^{18}$ roku, stała się podwaliną dwudziestowiecznej wampirycznej kultury popularnej. Interpretowano ją wielokrotnie oraz różnorodnie ${ }^{19}$. Na przykład na gruncie kog-

14 Wampir jest $w$ każdym z nas..., op. cit., s. 60.

15 Pojęcie rozwinięte i upowszechnione przez Victora Turnera, według którego liminalność jest stanem zawieszenia, jego wyznacznikami mają być m.in. odosobnienie, poniżenie, odwrócenie ładu, a przede wszystkim niezdefiniowana przynależność, zob. V. Turner, Gry społeczne, pola i metafory. Symboliczne działanie w społeczeństwie, przeł. W. Usakiewicz, Kraków 2005, s. 195-226.

16 Zob. A. van Gennep, Obrzędy przejścia. Systematyczne studium ceremonii, przeł. B. Biały, Warszawa 2006, s. 36.

17 W.J. Burszta, Antropologia kultury. Tematy, teorie, interpretacje, Poznań 1998, s. 106. Zob. także: A. Łuksza, Lowelas grobów: wampir na scenie w XIX wieku, „Literatura Ludowa” 2014, nr 2, s. 10 .

18 B. Stoker, Dracula, przeł. M. Król, Kraków 2008.

19 Zob. np. „Dracula”. The Vampire and the Critics, ed. M.L. Carter, Ann Arbor 1988. Bogaty przegląd bibliograficzny dotyczący interpretacji Draculi prezentuje Joanna Kokot, zob. J. Kokot, Pisanie jako modelowanie świata. „,Dracula” Brama Stokera, „Przegląd Humanistyczny” 2008, nr 5, s. 101-102. W świetle najnowszych badań niezwykle interesujący model interpretacji powieści Stokera przedstawił Hub Zwart, dostrzegając w niej odzwierciedlenie osiągnięć naukowych i technologicznych 
nitywistyki widziano $\mathrm{w}$ transylwańskim władcy hominida ${ }^{20}$, zgodnie $\mathrm{z}$ tezą, iż „wampir to człowiek, który w jakiś sposób został na nowo powołany do życia”21. W perspektywie filozoficznej działaniami głównego bohatera kieruje „metafizyczny sens”, mający „oddzielić ludzi od Dobra, uniemożliwić im kontakt z Absolutem"22. Wskazywano na diaboliczny kontekst Draculi, interpretowano jego postać jako wysłannika diabła ${ }^{23}$. Wampir „chrzci krwią” swoje żeńskie ofiary, tworzy krwawą eucharystię, potomstwo w wymiarze duchowym ${ }^{24}$, ,jest wcieleniem zła, które chce zniszczyć dobry cywilizowany świat”25. Bliskie takim rozpoznaniom interpretowanie z klucza fenomenologii religii pozwala dojrzeć w Stokerowym Draculi Antychrysta ${ }^{26}$.

Lata 70. przynoszą ważne utwory, domagające się uruchomienia interpretacji metafizycznych, ponieważ wampiry w tym okresie, oprócz postępującej seksualizacji (czy raczej wraz z nią), zaczęły być ukazywane jako byty podkreślające swój tragiczny status ontologiczny. Tym samym zaczyna się trwający do początku XXI wieku proces uczłowieczania wampira, oswajania się z nim, co widać szczególnie w powieści Anne Rice Wywiad z wampirem $(1976)^{27}$ oraz w filmie Wernera Herzoga Nosferatu wampir (1979) ${ }^{28}$. Elementem łączącym oba teksty kultury są egzystencjalne rozterki tytułowych krwiopijców. Dracula z filmu Herzoga skarży się na samotność, na wieczność, mówi do Jonathana Harkera: „Czas jest otchłanią sięgającą głębi tysiąca nocy. Mijają wieki, to straszne, gdy nie można się zestarzeć. Śmierć to nie wszystko, są rzeczy straszniejsze. Wyobraża pan sobie, że można przeżyć wieki i wciąż doświadczać tej samej marności?"29. W ujęciu niemieckiego reżysera wampiryzm oznacza przekleństwo. Dracula ma melancholijny wyraz twarzy; pożywianie się ludzką krwią stanowi dla niego tragiczny przymus, nie zaś źródło sensu bytowania, „osaczony przez własną nieśmiertelność jest nie panem życia ludzi, ale niewolnikiem własnego istnienia. Dopiero śmierć, jakkolwiek paradoksalnie to brzmi, wyzwala go od nieśmiertelności”" ${ }^{30}$.

ery fin de siècle'u, zob. H. Zwart, Vampires, Viruses and Verbalisation: Bram Stoker's Dracula as a genealogical window into fin-de-siècle science, „Janus Head” 2018, Vol. 16, s. 14-53.

20 Zob. K. Saja, Wampir w świecie antropii. Kognitywizm subsymboliczny w literaturoznawstwie, Kraków 2017, s. 124-147.

${ }^{21}$ Konstantinos, Wampiry wśród nas. Ukryta prawda, przeł. E. Androsiuk-Kotarska, Białystok 2012, s. 127.

22 A. Gemra, Od gotycyzmu do horroru. Wilkołak, wampir i Monstrum Frankensteina w wybranych utworach, Wrocław 2008, s. 164.

${ }^{23}$ Zob. ibid., s. 163-173.

24 Zob. ibid., s. 164-167.

25 K. Kaczor, Od Draculi do Lestata. Portrety wampira, Gdańsk 1998, s. 20.

26 Zob. M. Krysztofiak, Dracula Antychryst-watki religijne w literaturze wampirycznej, „Przegląd Religioznawczy” 2019, nr 4, s. 93-104. W artykule zostały przeanalizowane także inne utwory „spełniające dwa warunki: występowanie bohatera wampirycznego oraz optyki chrystianicznej”, ibid., s. 94.

27 A. Rice, Wywiad z wampirem, przeł. T. Olszewski, Poznań 2009.

28 Nosferatu wampir, reż. W. Herzog, Francja-RFN 1979.

29 Ibid., przeł. Augustyn Dobrzański.

30 P. Zwierzchowski, Smutek wiecznego życia. Filmowe wyobrażenia mitu o nieśmiertelności, „Kwartalnik Filmowy” 2003, nr 41-42, s. 288. 
U Rice wampir Louis nie może pogodzić się z wampiryczną dietą, nie chce zabijać ludzi, budzi to w nim odrazę od początku liminalnej egzystencji. Szacunek dla życia uwidacznia, jak bardzo rozdartym wewnętrznie jest wampirem. Stwierdza: „miałem wielki szacunek dla życia innych [...] Śmierć nigdy nie wywoływała u mnie rozbawienia, bez względu na to, jak często bywałem jej przyczyną" ${ }^{31}$; ,Jeżeli mogę żyć, karmiąc się krwią zwierząt, dlaczego nie powinienem żyć właśnie tak, zamiast poruszać się po świecie, przynosząc nieszczęścia i śmierć istotom ludzkim!'”32. Powieści Rice były interpretowane również z innego klucza filozoficznego, dzięki zastosowaniu pojęcia numinosum Rudolfa Otta oraz Kantowskiej kategorii wzniosłości ${ }^{33}$.

\section{Eksplikacje polityczne}

Zgodnie z rozpoznaniem Chantal Mouffe polityczność to „wymiar antagonizmu leżący u podstaw każdego społeczeństwa" ${ }^{34}$, a zatem to, co polityczne, jest nierozłączne od tego, co społeczne, ponieważ nieustająco zachodzą różnorodne procesy dialektyczne, co zostaje zobrazowane w kulturze. W przypadku wampiryzmu dialektyka jest widoczna jako zderzanie się dobra i zła, człowieka i bestii, wiary chrześcijańskiej i wierzeń pogańskich. W wieku XX pojawiły się polityczne wykładnie wampiryzmu ${ }^{35}$; próby nadpisywania do historii o krwiopijcach znaczeń ideologicznych - utożsamiania wampiryzmu z komunizmem czy kapitalizmem $^{36}$. W utworach bliskich poetyce horroru (szczególnie filmowych), jak stwierdza Janion, „odbija się zaniepokojenie społeczne, poczucie zagrożenia, które zarazem nie daje się zracjonalizować" ${ }^{37}$. W odczytaniach politycznych dominuje klarowny przekaz, nakierowanie społeczne, próba oddziaływania na odbiorcę w postaci przestrogi czy unaocznienia zagrożeń związanych z komunizmem/kapitalizmem (w zależności od przyjętej perspektywy światopoglądowej). Tym samym tekst kultury zaczyna pełnić funkcję użyteczną, staje się narzędziem ideologicznym.

Należy zaznaczyć, że najsłynniejszy utwór wampiryczny także podlegał tego typu odczytaniom. W rozumieniu politycznym i zarazem poststrukturalistycznym

31 A. Rice, op. cit., s. 32.

32 Ibid., s. 103.

33 Zob. P. Ciećwierz, Synowie Kaina, córy Lilith... Rzecz o wampirach w fantasy, Warszawa 2009, s. 89-103.

34 C. Mouffe, Polityczność, przeł. J. Erbel, Warszawa 2008, s. 24.

35 Warto zaznaczyć, że już w wieku XIX figura wampira służyła do metaforycznego utożsamiania go z kapitalizmem, co można odnaleźć chociażby w Kapitale Karola Marksa: „Kapitał jest pracą umarłą, która jak wampir ożywia się tylko wtedy, gdy wysysa żywą pracę, a tym więcej nabiera życia, im więcej jej wyssie", K. Marks, Kapitał. Krytyka ekonomii politycznej, t. 1, ks. 1, Proces wytwarzania kapitału, przeł. H. Lauer, M. Kwiatkowski, J. Heryng, L. Selen, Warszawa 2010, s. 332.

36 Podobne zjawisko interpretacji, według klucza politycznego, można zaobserwować w przypadku opowieści o zombie, zob. np. D.W. Drezner, Theories of International Politics and Zombies, Princeton 2011; M. Marcela, Monstruarium nowoczesne, Katowice 2015, s. 109-114.

37 M. Janion, Odnawianie znaczeń, op. cit., s. 346. 
Dracula z powieści Stokera staje się symbolem wyłączenia z porządku społecznego, ale również symbolicznego: „ucieleśnia w sobie wszystkich tych, którzy zostają wykluczeni ze społeczeństwa i przeciwko którym występuje rodząca się nowoczesna władza Rozumu"38. Interpretowano powieść w kategoriach lęku przed kulturą Wschodu i jako wyraz antysemityzmu ${ }^{39}$. Odczytywano hrabiego jako obcego wędrowca polującego na obywateli Zachodu, którzy nie należą do żadnego narodu ani klasy społecznej i są doświadczonymi podróżnikami. To, co nadaje ruchom tych postaci przywileje kulturowe, to ich zdolność do czerpania korzyści z mobilności, do przekształcania zmian miejsca w okazje do inwesty$\mathrm{cji}^{40}$. Dostrzegano, iż powieść koduje napięcia imperialistyczne między Anglią a Niemcami w sprawie południowoafrykańskich kopalni złota w Transwalu, ten zaś antagonizm stanowi tło wojny burskiej, która była prekursorska dla pierwszej wojny światowej ${ }^{41}$.

Omawiany proces egzegetyczny, inspirowany uwarunkowaniami politycznymi, najlepiej widać na przykładzie utworów z lat 50. i 60. XX wieku - Jestem legenda Richarda Mathesona ${ }^{42}$ (1954) oraz Nieustraszonych pogromców wampirów W reżyserii Romana Polańskiego ${ }^{43}$ (1967). W tych tekstach kultury dochodzi do odwrócenia klasycznego motywu walki dobra ze złem, ponieważ zło, czyli wampiry - zwyciężają. Co więcej, wampiryzm został ukazany jako choroba, zaraza, epidemia, która albo opanowuje miasto (tak się dzieje u Mathesona), albo opanuje niedługo cały świat (film Polańskiego). Tym samym łatwo było skojarzyć ową zarazę z komunizmem.

W przypadku powieści Mathesona na odczytanie polityczne duży wpływ miał początek zimnej wojny, społeczny klimat Stanów Zjednoczonych lat 50., zjawisko maccartyzmu ${ }^{44}$. Interpretacja powieści nasuwała się sama - tak jak w Jestem legenda wampiry opanowują Stany Zjednoczone, tak samo uczynią to niedługo komuniści. W dodatku krwiopijcy tworzą ,społeczeństwo-monolit, w którym wszyscy będą mieli jednakowe poglądy; system totalitarny, w którym [...] może

38 M. Marcela, op. cit., s. 11.

39 Zob. C.M. Davison, Anti-Semitism and British Gothic Literature, New York 2004, s. 120-157; K.P. Zurutuza, The Vampire as the Gender and Racial Construction of Western Capitalism's White Masculinity in English and American Gothic Literature, „International Journal of Arts \& Sciences” 2015, Vol. 8, s. 543-544.

40 Zob. P. McKee, Racialization, Capitalism, and Aesthetics in Stoker's “Dracula”, „Novel” 2002, Vol. 36, No. 1, s. 42-60.

41 S. Shapiro, Transvaal, Transylvania: Dracula's World-system and Gothic periodicity, „Gothic Studies" 2008, Vol. 10, No. 1, s. 29-47.

42 R. Matheson, Jestem legenda, przeł. W. Kustra, Katowice 1992.

43 Nieustraszeni pogromcy wampirów albo: Przepraszam, ale pańskie zęby tkwią w mej szyi, reż. R. Polański, USA-Wielka Brytania 1967.

44 Szeroko zakrojony program działań, który nazwę wziął od nazwiska republikańskiego senatora Josepha McCarthy’ego, miał na celu walkę z działalnością komunistyczną wewnątrz kraju. Wytworzył atmosferę strachu i podejrzeń, zob. G. Hodgson, The Myth of American Exceptionalism, New Haven-London 2009, s. 58. Ważną odpowiedzią artystyczną na ten trudny czas w historii USA był dramat Arthura Millera Czarownice z Salem z 1952 roku (zob. A. Miller, Czarownice z Salem, przeł. A. Bańkowska, Warszawa 2009). 
istnieć tylko jedna ideologia"45. Wiele lat później pojawiły się także interpretacje, które badały związek między kapitalizmem a seksualnością w powieści Matheso$\mathrm{na}^{46}$, a także relacje rasy oraz męskości ${ }^{47}$.

Nakręcony trzynaście lat po Jestem legendq i pięć lat po kryzysie kubańskim (1962) film Polańskiego, w którym wampiry marzą o podbiciu świata, a końcówka utworu zapowiada, że już niedługo z pewnością im się to uda, skłaniał do podobnych wniosków co powieść Mathesona. Interpretowano Transylwanię z Nieustraszonych pogromców wampirów jako Związek Radziecki wraz z jego dominacją nad zastraszonymi katolickimi sąsiadami, a jeżeli jeszcze do tego dodać kolor czerwony, związany z wampirami (krew), utożsamienie ich z komunizmem było nadzwyczaj oczywiste ${ }^{48}$.

W odniesieniu do politycznych znaczeń wampiryzmu w obrębie kultury polskiej Janion doszła do wniosku, że „losy Polaków łączą się ściśle z losami ich upiorów, a zwłaszcza wampirów"49, czego najlepszą egzemplifikację stanowią utwory romantyczne. W III części Dziadów Adama Mickiewicza Konrad śpiewa wampiryczną pieśń zemsty: „Pieśń ma była już w grobie, już chłodna, — / Krew poczuła: z pod ziemi wygląda, / I jak upiór powstaje krwi głodna, / I krwi żąda, krwi żąda, krwi żąda / Tak! zemsta, zemsta, zemsta na wroga, / Z Bogiem i choćby mimo Boga!”50. Wampiryczny śpiew Konrada - pod względem „potęgi patriotycznej dzikości, nienawiści i mściwości nie dający się z niczym w literaturze polskiej porównać" ${ }^{51}$. Pojawia się tu „transgresja patriotyczna" ${ }^{52}$, a więc przekroczenie osobowości. Wampiryzm Konrada jest szczególny, bo właśnie patriotyczny, żąda ofiary z krwi, by „braci rodaków” zarazić pragnieniem zemsty na zaborcach Rzeczypospolitej, „to, co się dzieje w aurze wampirycznej, oczywiście odbiega od polskiego kanonu heroicznego" ${ }^{53}$. Warto pamiętać, że pojawiający się w twórczości Mickiewicza patriotyczny wampiryzm zemsty nie jest odosobniony w polskiej literaturze romantycznej, czego dowód stanowi chociażby wiersz Leona Kaplińskiego Zgasty dla nas nadziei promienie... ${ }^{54}$.

Pozostając w obszarze politycznych odczytań wampiryzmu, warto zaznaczyć, że nie ograniczają się one wyłącznie do utworów literatury XIX wieku czy tych,

45 A. Gemra, Od gotycyzmu do horroru..., op. cit., s. 213.

46 Zob. np. J. Khader, Will the Real Robert Neville Please, Come Out? Vampirism, the Ethics of Queer Monstrosity, and Capitalism in Richard Matheson's “I Am Legend”?, ,Journal of Homosexuality” 2013, Vol. 60, No. 4, s. 532-557.

47 Zob. A.J. Ransom, "I Am Legend" as American Myth: Race and Masculinity in the Novel and Its Film Adaptations, Jefferson 2018.

48 Zob. G. Stachówna, Roman Polański i jego filmy, Warszawa 1994, s. 182-183.

49 M. Janion, Wobec zła, Chotomów 1989, s. 33.

50 A. Mickiewicz, Dziady, część trzecia, oprac. J. Kallenbach, BN I 20, Kraków 1920, s. 77.

51 M. Janion, Wobec zła, op. cit., s. 33.

52 Wampir jest $w$ każdym z nas..., op. cit., s. 62.

53 Reduta. Magnetofonowy zapis dyskusji, która odbyla się 23 lutego 1980 roku w Teatrze „,Wybrzeże” w Gdańsku po przedstawieniu „Dziadów” Adama Mickiewicza w reżyserii Macieja Prusa, wypowiedź Marii Janion, oprac. D. Szkop-Dąbrowska, „Punkt” 1981, nr 13, s. 12.

54 Zob. L. Kapliński, Zgasty dla nas nadziei promienie... [w:] M. Janion, Reduta. Romantyczna poezja niepodległościowa, Kraków 1979, s. 280-281. 
które powstały w latach 50. i 60. wieku XX. Przykład upolitycznionej interpretacji wampiryzmu stanowi artykuł Spójrz w twarz wampira Mateusza Myślickiego, który doszukuje się w serialu Czysta krew ${ }^{55}$ (pierwszy sezon powstał w 2008 roku) lewicowo-liberalnej poprawności politycznej ${ }^{56}$, co zostaje odnotowane w sposób jednoznacznie negatywny. Z kolei Joanna Ostrowska dostrzega w tejże produkcji telewizyjnej walkę mniejszości społecznej (wampirów) o swoje prawa ${ }^{57}$. W tego typu interpretacjach, bez względu na zajmowane stanowisko polityczne, nie brakuje kategorycznych konstatacji, exemplum teza Jakuba Majmurka: „Wampiry symbolizują dekadencką klasę wyższą, która - choć już dawno powinna zejść ze sceny historii - uparcie trzyma się władzy i przywilejów, wysysając żywotne soki z gorzej urodzonych nieszczęśników"58. Warto jednak pamiętać o spostrzeżeniu Michała Pawła Markowskiego: „Jeśli sztuce przypisuje się jakąkolwiek z góry wybraną rolę do pełnienia, traci ona tym samym swój krytyczny charakter. Zyskuje go, gdy opiera się zadaniom krytyki politycznej”59.

\section{Gender i queer}

Wampir, przedstawiany w kategoriach pożądania heteroseksualnego, zaczął być także rozpatrywany w wyobrażeniach homoerotycznych, zarówno kobiecych, jak i męskich. Wpływ na ten fakt miał charakter kultury popularnej, która jest „tym, co z nią czynimy - wrogiem, zagrożeniem, zniewalającą siłą i narzędziem panowania, środkiem emancypacji”" ${ }^{00}$. Kultura popularna stwarza przestrzeń, w której doszło i dochodzi do uniezależnienia się różnych mniejszości, w tym seksualnych. Utwory gotyckie będące podwaliną popkultury, takie jak Carmilla Josepha Sheridana Le Fanu ${ }^{61}$ czy Dracula Stokera, zawierały jawne lub sygnalizowane motywy homoerotyczne ${ }^{62}$.

Ważną rolę odegrała perspektywa psychoanalityczna, która w znaczący sposób wpłynęła na badania genderowe $\mathrm{e}^{63}$. Janion odnotowuje, że w filmowych adaptacjach najsłynniejszej powieści Stokera z lat 1930-1968, zgodnie z rozpoznaniami Rogera Dadouna, widoczny jest „ekshibicjonizm falliczny [...] związany z archaiczną matką" ${ }^{64}$. Z kolei w perspektywie lacanowskiej Alain Roger

55 Czysta krew, reż. A. Ball, USA 2008.

56 M. Myślicki, Spójrz w twarz wampira. ,, True Blood” jako horror zaangażowany w perspektywie teorii inności [w:] Światy grozy, red. K. Olkusz, Kraków 2016, s. 151-163.

57 Zob. J. Ostrowska, ,C Czysta krew”, czyli jak demoniczna mniejszość przejmuje władzę! [w:] Seriale. Przewodnik Krytyki Politycznej, Warszawa 2011, s. 291-296.

58 J. Majmurek, Dekada horroru, „Pismo” 2019, nr 5, s. 82.

59 M.P. Markowski, Nieobliczalne. Eseje, Kraków 2007, s. 198.

60 M. Krajewski, Kultury kultury popularnej, Poznań 2005, s. 11.

61 J.S. Le Fanu, Carmilla, przeł. M. Kozłowski, Kraków 1974.

62 Wielokrotnie brany na warsztat filmowy utwór Stokera doczekał się licznych interpretacji queerowych, zob. np. M. Janion, Wampir. Biografia ..., op. cit., s. 198-199; P. Kletowski, Nosferatu [w:] K.M. Śmiałkowski, Wampir. Leksykon, Bielsko-Biała 2010, s. 32; B. Paszylk, Leksykon filmowego horroru, Michałów-Grabina 2006, s. 15.

${ }^{63}$ Zob. P. Dybel, Zagadka „,drugiej ptci”. Spory wokół różnicy seksualnej w psychoanalizie i feminizmie, Kraków 2012.

64 Zob. M. Janion, Wampir. Biografia..., op. cit., s. 197. 
„umieszcza [...] Draculę również w polu archaicznej matki, pisząc o jej wyobrażonym fallusie jako «fallucynacji»" ${ }^{\circ}$. W poetyce genderowej hrabia jawi się jako wampir będący „figurą wiecznego pożądania - i to zarówno męskiego, jak kobiecego, homo- i heteroseksualnego"66. Pisano o Draculi, że ,jest uosobieniem mrocznej, perwersyjnej strony seksu" ${ }^{67}$. Właśnie w erotycznym nacechowaniu wampira upatrywano źródła jego popularności: „Stokerowi udało się ożywić legendę o wampirach głównie dzięki temu, że stworzył powieść rozsadzaną przez energię seksualną" ${ }^{\prime 68}$. Ukazywano na konkretnej czynności hrabiego jego seksualizm: ,perwersyjny pocałunek Draculi złożony na szyi ofiary jest aktem wyraźnie seksualnym. Upuszczenie krwi kobietom przez wampira psychoanaliza wiąże z czynnością seksualną" ${ }^{99}$.

Tekst kultury popularnej jest obszarem umożliwiającym manifestowanie homoseksualnej odmienności. Należałoby ją tłumaczyć, zgodnie z wykładnią Julii Kristevej, jako podmiotowość, w którą wpisana jest swojska obcość, niesamowitość ${ }^{70}$. Wampir w tym paradygmacie staje się abiektem, „,wzbudza tyleż wstręt, co i fascynację. [...] abiekt tkwi we wnętrzu podmiotu. Skoro szukamy i zabijamy kozła ofiarnego, nie potrafiliśmy poradzić sobie z własnym abiektem w nas [...] abiekt wymyka się temu, co społeczne. Znajduje się on poza ściśle wytyczonymi granicami, rozdziałami, oddzieleniami. Aspołeczny, pogardzany, nieczysty abiekt przeraża i fascynuje zarazem"’1.

\section{Mit kultury popularnej - perspektywa semiologiczna}

Wampir był rozpatrywany w kategoriach mitu w wymiarze podwójnym - zarówno przez jego mityczne pochodzenie i uwarunkowania folklorystyczne, jak i funkcjonowanie w obrębie popkultury. Wampir stanowi mit kultury popularnej. Roland Barthes zauważał, że „mitologia jest zgodą na świat nie taki, jaki jest, ale na taki, jaki chce się stworzyć" ${ }^{\prime 2}$. Dla francuskiego uczonego mit to opowiadanie o udziale człowieka w kulturze popularnej, więc w tym rozumieniu wampir będzie produktem ludzkiej wyobraźni, fantazmatem. Takie rozumienie jest kompatybilne z konstatacją Jurija Łotmana i Zary Minc, którzy piszą: „wyjątkowo podatny grunt dla tworzenia mitów stanowi kultura masowa $\mathrm{z}$ jej skłonnością do uproszczonych uogólnień"ᄁ3.

65 Ibid., s. 198.

66 Ibid., s. 194.

67 S. King, Danse Macabre, przeł. P. Braiter, P. Ziemkiewicz, Warszawa 2009, s. 91.

68 Ibid. Zob. także: J.A. Stevenson, A Vampire in the Mirror: The Sexuality of “Dracula”, „PMLA” 1988, Vol. 103, No. 2, s. 139-149.

69 I. Kolasińska, Zęby wampira - dyskretny urok pożądania [w:] Niedyskretny urok kiczu. Problemy filmowej kultury popularnej, red. G. Stachówna, Kraków 1997, s. 57.

70 Zob. T. Kitliński, Obcy jest w nas. Kochać wedtug Julii Kristevej, Kraków 2001, s. 14.

71 J. Kristeva, Potęga obrzydzenia. Esej o wstręcie, przeł. M. Falski, Kraków 2007, s. 10.

72 R. Barthes, Mitologie, przeł. A. Dziadek, Warszawa 2000, s. 293.

73 J. Łotman, Z. Minc, Literatura i mitologia [w:] Sztuka w świecie znaków, oprac. i przeł.

B. Żyłko, Gdańsk 2002, s. 81. 
Wampir w kulturze popularnej XX i XXI wieku nie jest niczym innym jak „uproszczonym uogólnieniem” w stosunku do wampira, który istniał w mitologii słowiańskiej i innych mitologiach świata, czy nawet w literaturze romantycznej, biorąc pod uwagę jego nowe, estetyczne ujęcie, jak bowiem przypomina Umberto Eco - powieść popularna „redukuje do kliszy twórcze rozwiązania dawniejszej literatury" ${ }^{\prime 4}$. Figura wampira jest degradowana poprzez kolejne reinterpretacje oraz redukcje dokonywane w obrębie kultury popularnej. Od Draculi Stokera do Zmierzchu Stephenie Meyer ${ }^{75}$, w ciągu ponad 100 lat, wampir stracił przypisywane mu w romantyzmie czy w ujęciach ludowych elementy funkcjonowania: poruszanie się wyłącznie w nocy, odżywianie ludzką krwią, strach przed symbolami chrześcijańskimi itp. Unieważnione zostały tradycyjne sposoby jego zgładzenia.

Postępująca estetyzacja i seksualizacja, a także związana z tymi zjawiskami banalizacja figury krwiopijcy, miały przełożenie na kwestie genologiczne. Wampiryczne opowieści ewoluowały od XIX do XX wieku w myśl zasady „od gotycyzmu do horroru" ${ }^{\text {", }}$, natomiast od końca XX do XXI wieku - od horroru do romansu. Dracula Stokera realizuje cechy powieści gotyckiej, Miasteczko Salem Stephena Kinga czy Nosferatu wampir w reżyserii Herzoga stanowią egzemplifikacje klasycznego horroru, w którym ,potwór jawi się jako coś nienormalnego, zaburzenie naturalnego porządku" "77, natomiast tetralogia Zmierzch czy serial Czysta krew posiadają typowe elementy powieści romansowej z jej stereotypami oraz uproszczoną fabułą. Pojawiają się w nich identyczne struktury narracyjne ${ }^{78}$, podobnie jak w utworach, które powstały na fali popularności Zmierzchu, eksploatujące motyw miłości wampira i nastolatki ${ }^{79}$.

W 2005 roku Meyer opublikowała wspomnianą powieść Zmierzch, będącą pierwszą częścią tetralogii opowiadającej o miłości nastolatki Isabelli Swan i wampira Edwarda Cullena. Reinterpretacja postaci krwiopijcy dokonana przez amerykańską pisarkę poszła bardzo daleko: wampira nie można unicestwić inaczej niż poprzez pokawałkowanie jego ciała oraz spalenie; porusza się on nawet w czasie solarnym. Pozornie rodzina Cullenów nie różni się w swoim codziennym funkcjonowaniu od ludzi poza tym, że ich pożywienie stanowi krew zwierząt. Jej członkowie nie starzeją się, są niewiarygodnie silni, a niektórzy obdarzeni magicznymi mocami. Przede wszystkim dochodzi do zaprzeczenia logiki

74 U. Eco, Superman w literaturze masowej. Powieść popularna: między retoryka a ideologia, przeł. J. Ugniewska, Kraków 2008, s. 18.

75 S. Meyer, Zmierzch, przeł. J. Urban, Wrocław 2009.

76 Zob. A. Gemra, Od gotycyzmu do horroru..., op. cit.

77 N. Carroll, Filozofia horroru albo paradoksy uczuć, przeł. M. Przylipiak, Gdańsk 2004, s. 37.

78 Zob. B. Darska, Od potwora do wymarzonego kochanka. O zmieniajacym się kulturowym wizerunku wampira, „Media - Kultura - Komunikacja Społeczna” 2016, t. 12, nr 1, s. 97.

79 Zob. K. Olkusz, Rozbieranie wampira. Erotyczne imaginacje i seksualne fantazje w romansach paranormalnych/metafizycznych (na wybranych przykładach), „Orbis Linguarum” 2015, nr 43, s. 415425; eadem, W objęciach kiczu, czyli co skrywa (lub odstania) romans paranormalny/metafizyczny. Na przyktadzie cyklu „Love at Stake” Kerrelyn Sparks [w:] Literatura i kultura popularna. Badania i metody, red. A. Gemra, A. Mazurkiewicz, Wrocław 2014, s. 149-160. 
Świata wampirycznego, znanej z utworów wcześniejszych ${ }^{80}$ - miłości pomiędzy człowiekiem a wampirem.

Tetralogia Zmierzch, która jedynie pozornie stała się ostatnim etapem seksualizacji wampira w kulturze popularnej, jest precyzyjnym odwróceniem dotychczasowego schematu kulturowego związanego z gotycyzmem. Na tle swoich literackich i filmowych antenatów, pod względem zobrazowania relacji rodzinnych, a przede wszystkim damsko-męskich, damsko-damskich i męsko-męskich, cykl Zmierzch jest najbardziej konserwatywny, tradycyjny oraz stereotypowy. We wcześniejszych, wspominanych powyżej, utworach, takich jak: Carmilla, Dracula, Miasteczko Salem, Wywiad z wampirem, w których pojawiają się związki homoseksualne, następuje rozpad typowego modelu rodziny. Zmierzch stanowi ich całkowite zaprzeczenie. Nie można zatem zgodzić się z rozpoznaniem Ireneusza Gielaty i Ryszarda Koziołka, którzy twierdzą, że główna bohaterka powieści: „Bella jest spadkobierczynią pokolenia rewolucji seksualnej, która szczęście człowieka związała ze stanem erotycznej wolności" ${ }^{21}$. Bella nie potrzebuje erotycznej wolności, nie korzysta z niej, nie chce, wybiera i wpisuje się w tradycyjny, konserwatywny model rodziny, który wcześniejsze utwory konsekwentnie dekonstruowały.

Powieści Meyer otwierają bardzo szerokie perspektywy badawcze, były rozpatrywane w kategoriach mitograficznych ${ }^{82}$, genderowych, feministycznych, filozoficznych, socjologicznych ${ }^{83}$, historycznych ${ }^{84}$, medioznawczych ${ }^{85}$, a także pojawiły się propozycje interpretowania Zmierzchu w optyce religijnej ${ }^{86}$ czy psychologicznej ${ }^{87}$. Podobnie serial Czysta krew, który powstał na fali popularności utworów Meyer, doczekał się różnorodnych odczytań ${ }^{88}$.

80 W literaturze dziewiętnastowiecznej, np. w Carmilli Josepha Sheridana Le Fanu z 1872 roku, w której bardzo wyraźnie zaznaczony jest motyw seksualnej relacji człowieka z wampirem, aspekt erotyczny wysuwa się na pierwszy plan, a wszelkie uczucia wyższe, takie jak miłość, nie mają racji bytu. Z podobną sytuacją czytelnik spotyka się w Draculi Stokera; chociaż już słynna filmowa adaptacja tej powieści, dokonana przez Francisa Forda Coppolę, przynosi wizerunek wampira zakochanego w kobiecie, a nawet uzasadnia genezę wampiryzmu tytułowego bohatera poprzez miłość, zob. Dracula, reż. F.F. Coppola, USA 1992.

81 I. Gielata, R. Koziołek, Coraz piękniejsze potwory, „Świat i Słowo” 2012, nr 1, s. 11.

82 Zob. G. Lasoń-Kochańska, Śmiertelne zaślubiny. Mit i tajemnica w cyklu ,Zmierzch” Stephenie Meyer [w:] Mit-literatura-tajemnica, red. W. Gruszczyński, T. Ratajczak, B. Trocha, Zielona Góra 2013, s. 147-155.

83 Zob. Zmierzch i filozofia. Wampiry, wegetarianie i pogoń za nieśmiertelnościa, oprac. W. Irwin, J.J. Wisnewski, R. Housel, przeł. A. Krzysztoń, J. Urban, Warszawa 2009.

${ }^{84}$ Zmierzch i historia, red. N.R. Reagin, przeł. E. Siarkiewicz, P. Żak, Warszawa 2010.

85 Zob. M. Kita, Tekstowo zmediatyzowane doświadczenie bycia wampirem. Wokót „Zmierzchu” Stephenie Meyer, „Język Artystyczny” 2014, t. 15, s. 35-64.

86 Zob. J. Riess, Book of Mormon Stories That Steph Meyer Tells to Me: LDS Themes in the Twilight Saga and The Host, „BYU Studies Quarterly” 2019, Vol. 48, s. 141-147.

${ }_{87}$ Zob. A. Fetters, At Its Core, the “Twilight” Saga Is a Story About, ,The Atlantic” 2012, Nov. 15, https://www.theatlantic.com/entertainment/archive/2012/11/at-its-core-the-twilight-saga-is-a-storyabout/265328/ (dostęp: 9.01.2021).

88 Zob. Czysta krew i filozofia. Wampiry staja się naprawdę niegrzeczne, red. W. Irwin, G.A. Dunn, R. Housel, przeł. K. Schmidt, Gliwice 2010. 


\section{Perspektywa etyczna}

Wydaje się, że dość pomijanym w studiach nad wampiryzmem aspektem interpretacyjnym jest perspektywa etyczna, aksjologiczna, moralna. Schyłek XX i początek XXI wieku przyniósł obrazy wampirów oswojonych, nawiązujących pozornie normalne, jeżeli za normalne można uznać relacje człowieka z pasożytem, stosunki z ludźmi. Oto pojawiły się wampiry rezygnujące z picia ludzkiej krwi (Wywiad z wampirem), przyjaźniące się z dziećmi ${ }^{89}$ (Wpuść mnie ${ }^{90}$, Mój nauczyciel jest... wampirem $^{91}$, Wampiurek $^{92}$ ) i przede wszystkim te, które pod postacią herosów ratują swe wybranki czy wybranków przed grożącym im (nie ze strony wampira) niebezpieczeństwem, żeby wspomnieć cykl Zmierzch czy serial Czysta krew. Fantazmaty, jakie uwalniają wspomniane utwory, którymi karmią się nastolatkowie, pozostaną jedynie fantazmatami, a one, jak podkreśla Janion, mogą być „kojące, uśmierzające, łagodzące, ale również koszmarne, dławiące strachem, przerażające (wystarczy porównać koncepcję das Unheimliche)"93.

Kultura popularna XX i XXI wieku ,pięknie oswaja brutalność”"94, jak zauważył Łukasz Orbitowski, komentując filmy Christophera Nolana o Batmanie. Zło zostało oswojone, zaakceptowane, jego nieodparta, emanująca siła zwodzi i zachęca, wydaje rozkaz: „wpuść mnie”, jak wampiryczna bohaterka wspomnianej powieści Johna Ajvide'a Lindqvista. Wampiry, wpuszczone w zacisza domostw, do dziecięcych i młodzieżowych sypialni, do bloków na szwedzkich osiedlach i domków w peryferyjnych miastach Stanów Zjednoczonych, stały się przyjaciółmi, kochankami, powiernikami, bohaterami. Diagnoza etyczna tego procesu skłania do zatrważających wniosków. Wampiry zatraciły swoją morderczą grozę na rzecz erotycznej aury, przeszły drogę, którą Anna Gemra podsumowała słowami „od zera do bohatera” ${ }^{5}$. Również Rafał Nawrocki celnie komentuje omawiany stan rzeczy: „wampiry i wilkołaki znalazły się w ofercie dla wszystkich grup wiekowych, stały się propozycją równie powszechną w kulturze, co ziemniaki w kuchni wielkopolskiej"'96.

89 Na temat wampira w literaturze dla młodego odbiorcy jako monstrum oswojonego zob. K. Slany, Groza w literaturze dziecięcej. Od Grimmów do Gaimana, Kraków 2016, s. 237-238; K. Tałuć, Horror w tekstach dla młodego odbiorcy (rekonesans badawczy) [w:] Nowe opisanie świata. Literatura i sztuka dla dzieci i młodzieży w kręgach oddziaływań, red. B. Niesporek-Szamburska, M. Wójcik-Dudek, Katowice 2013, s. 41-54.

90 J.A. Lindqvist, Wpuść mnie, przeł. E. Frątczak-Nowotny, Warszawa 2008.

91 J. Piasecki, Mój nauczyciel jest... wampirem, przeł. C. Frąc, Warszawa 2002.

92 R. Welsh, Wampiurek, przeł. A. Oczko, Warszawa 2005.

93 M. Janion, Projekt krytyki fantazmatycznej..., op. cit., s. 25.

94 Ł. Orbitowski, Arcytotry Ameryki, „Gazeta Wyborcza” 2012, nr 169, s. 12.

95 A. Gemra, Od zera do bohatera: ewolucja statusu wampira $w$ wybranych utworach [w:] „Homo mythicus” i mityczne wzorce tożsamości, red. H. Kubicka, G. Trębicki, B. Trocha, Zielona Góra 2014, s. 55-73.

96 R. Nawrocki, Zmierzch bezpieczeństwa oświeceniowych paradygmatów i jutrzenka stereotypu popkultury: gotycyzm i preromantyzm, „Świat i Słowo” 2013, nr 2, s. 92-93. Zob. także: B. Darska, op. cit., s. 93-102; A. Mazurkiewicz, Potomkowie hrabiego Draculi - szkic do portretu (o recepcji motywów wampirycznych we wspólczesnej literaturze), „Literaturoznawstwo” 2007, nr 1, s. 222-224. 


\section{Miasteczko Salem Stephena Kinga - heterogeniczność interpretacji}

Wielowariantowość kierunków interpretacji wampiryzmu najefektowniej można zaprezentować na przykładzie Miasteczka Salem Kinga, ponieważ w tej powieści autor skupił, niczym w soczewce, wszelkie możliwe wampiryczne i okołowampiryczne motywy ${ }^{97}$, nie zapominając o dorobku swoich antenatów, w tym szczególnie Stokera. Miasteczko Salem można odczytywać jako:

Utwór w perspektywie metafizycznej, w którym zostaje przedstawiony problem dobra i zła. Wampiryzm „nie jest czymś zewnętrznym, lecz tym, co się nosi w sobie samym; [...] jest brakiem sprzeciwu wobec zła, oportunizmem"98. Wampir z powieści to wampir wewnętrzny, tkwiący w człowieku. Nadejście Kurta Barlowa jest ostatecznym zwycięstwem zła, które żyło w miasteczku od dawna: „kiedy pojawia się zło, jego nadejście wydaje się czymś od dawna przepowiedzianym, słodkim i uspokajającym, zupełnie jakby miasto wiedziało, pod jaką tym razem postacią zjawi się ów nieproszony gość"

Utwór w perspektywie genderowej, w którym seksualność staje się tematem wiodącym dla zrozumienia fascynacji, jaką budzi wampir. W tym aspekcie uwypuklony zostaje panseksualizm wampirów. U Kinga wyraźnie widać, jak przeobrażenie w krwiopijcę pozwala mieszkańcom spełniać wszelkie pragnienia: „George Middler zaś zjawił się z wizytą u kilku spośród dokonujących zawsze u niego zakupów chłopców, zwykle przyglądających mu się spod oka albo z domyślnym uśmieszkiem na ustach; wreszcie mógł zrealizować swoje najbardziej mroczne fantazje" ${ }^{100}$.

Utwór w perspektywie krytyki fantazmatycznej, opowiadający o wampirze jako konstrukcie wyobraźni, fantazmacie, uosobieniu i odbiciu ludzkich lęków oraz pragnień. $\mathrm{W}$ tym paradygmacie wymagane byłoby również sięgnięcie po instrumentarium psychoanalityczne.

Utwór w perspektywie badań nad intertekstualnością, polifoniczny, będący literacką grą z Dracula Stokera ${ }^{101}$ (do czego wprost przyznawał się autor ${ }^{102}$ ).

Utwór w perspektywie socjologicznej, w którym zostaje postawiona diagnoza względem peryferyjnego miasteczka i relacji w nim panujących.

97 W kinie początku XXI wieku podobnym do Miasteczka Salem (pod względem nagromadzenia motywów oraz stereotypów wampirycznych) jest film Postrach nocy, reż. C. Gillespie, USA 2011, stanowiący remake obrazu z 1985 roku (zob. Postrach nocy, reż. T. Holland, USA 1985), jednak pierwowzór z lat 80. nie obejmował wszystkich aspektów wampiryzmu, np. jego homoerotycznej odsłony, a z kolei taki wątek jest zasygnalizowany w Postrachu nocy z 2011 roku. Wydaje się, że ten temat wymaga osobnego opracowania.

98 A. Gemra, Od gotycyzmu do horroru..., op. cit., s. 225.

99 S. King, Miasteczko Salem, przeł. A. Nakoniecznik, Warszawa 2012, s. 267.

100 Ibid., s. 511.

101 Zob. A. Gemra, Od gotycyzmu do horroru..., op. cit., s. 226; R. Lidston, Dracula and Salem's Lot: Why the Monsters Won't Die, ,West Virginia University Philological Papers” 1982, Vol. 28, s. 70-78; J.S. Sanders, Closure and Power in Salem's Lot, ,Journal of the Fantastic in the Arts” 1999, Vol. 10, s. 145 .

102 Zob. S. King, Danse Macabre, op. cit., s. 46-48; idem, Jak pisać. Pamiętnik rzemieślnika, przeł. P. Braiter, Warszawa 2014, s. 177; R. Ziębiński, Stephen King. Instrukcja obstugi, Warszawa 2019, s. 57-58. 
Utwór w perspektywie postkolonialnej, w którym pogardzane peryferie stają się królestwem wampirów, a dotychczasowe centrum, ogniskujące się wokół metropolii, zostaje zdetronizowane. To już nie wielkie miasto, jak Londyn z Draculi Stokera czy Nowy Orlean lub Paryż z Wywiadu z wampirem Rice, jest miejscem bytowania i działalności krwiopijcy, tylko peryferyjne miasteczko, prowincja.

Utwór w perspektywie semiologicznej, w którym wampir jest mitem podwójnym - wynikającym z wierzeń Słowian, o ludowej proweniencji oraz (zgodnie z koncepcją Barthes'a) mitem współczesnym, kulturowym.

Utwór w perspektywie odczytań politycznych, w wymiarze marksistowskim, w którym władza i pieniądze, bezwzględność i chciwość zdominowały relacje międzyludzkie, gdzie dochodzi do uwspółcześnionej walki klas, wampir staje się symbolem kapitalizmu ${ }^{103}$, a także globalizacji, jeżeli wziąć pod uwagę, że Barlow tworzy z mieszkańców Salem homogeniczne społeczeństwo, sam wampiryzm zaś został importowany do Stanów Zjednoczonych z Europy Wschodniej.

Oprócz wyżej wymienionych strategii lekturowych można interpretować Miasteczko Salem, uruchamiając wyodrębnione paradygmaty lub łącząc je w objaśnianiu konkretnych motywów, np. dzieci (w czym pomocna byłaby dyscyplina children's studies) czy wiary chrześcijańskiej (wchodząc w horyzont odczytań fenomenologicznych lub hermeneutycznych). Eklektyzm metodologiczny zawsze sprzyja interpretowaniu zjawisk pojemnych, wieloznacznych, heterogenicznych, a przede wszystkim tak bogato reprezentowanych w kulturze jak wampiryzm.

\section{Konkluzje}

Krwiopijca inspirował i inspiruje nie tylko artystów, ale również interpretatorów. Przedstawiony w powyższym artykule przegląd ważniejszych stanowisk egzegetycznych tekstów przynależnych do wampirycznej kultury popularnej nie wyczerpuje zagadnienia. W dhugiej tradycji interpretacji i tłumaczenia kulturowego zjawiska wampiryzmu sięgano po wszelakie praktyki objaśniające.

Konkludując, zdecydowana różnorodność sposobów lektury potwierdza przytoczone na wstępie stanowisko, według którego wampir cieszy się niezmienną od lat popularnością, warunkowaną swoim transgresyjnym, nieoczywistym charakterem, a także tym, że stanowi zwierciadło ludzkiego istnienia. Przede wszystkim czytanie opowieści o wampirach jest wielowariantowe, w trakcie lektury i pogłębionej analizy uruchamiają się rozmaite sensy oraz konteksty, otwierające różnorodne znaczenia ${ }^{104}$. Tym samym nie istnieje jedna, określona metoda czy wybór

103 Zob. G.N. Bauer, „Christ, what a dead little place”: Compulsive Consumption in Stephen King's Salem's Lot, „Studies in Gothic Fiction” 2015, Vol. 4, No. 1/2, s. 18-29.

104 Szczególnie w literaturze anglojęzycznej nie brakuje syntetycznych opracowań utworów wampirycznych, prezentujących także uwarunkowania metodologiczne, zob. N. Groom, The Vampire: A New History, New Haven-London 2018. Na polskim gruncie badawczym (oprócz cytowanych w niniejszym artykule książek i rozpraw) warta odnotowania jest książka Michała Wolskiego, stanowiąca bogaty przegląd typologii antybohaterów wampirycznych występujących w kulturze popularnej XX i XXI wieku, chociaż inspirowana przede wszystkim perspektywą imaginologiczną, badaniami nad strukturami wyobrażeniowymi, dzięki skrupulatnie zebranemu stanowi badań nad 
metod najbardziej adekwatnych do interpretowania zjawiska wampiryzmu. Tak jak wampir jest wieloznaczny, tak samo sposób jego odczytania będzie namnażał sensy i otwierał konteksty, będzie prowokował do stawiania śmiałych hipotez i burzenia określonych porząaków egzegetycznych.

\section{Bibliografia (References)}

Ariès P., Człowiek i śmierć, przeł. E. Bąkowska, Warszawa 1992.

Barthes R., Mitologie, przeł. Adam Dziadek, Warszawa 2000.

Bauer G.N., ,,Christ, what a dead little place”: Compulsive Consumption in Stephen King's Salem's Lot, „Studies in Gothic Fiction” 2015, Vol. 4, No. 1/2.

Brückner A., Mitologia stowiańska i polska, Warszawa 1980.

Burszta W.J., Antropologia kultury. Tematy, teorie, interpretacje, Poznań 1998.

Carroll N., Filozofia horroru albo paradoksy uczuć, przeł. M. Przylipiak, Gdańsk 2004.

Ciećwierz P., Synowie Kaina, córy Lilith... Rzecz o wampirach w fantasy, Warszawa 2009.

Czysta krew i filozofia. Wampiry staja się naprawdę niegrzeczne, red. W. Irwin, G.A. Dunn, R. Housel, przeł. K. Schmidt, Gliwice 2010.

Darska B., Od potwora do wymarzonego kochanka. O zmieniajacym się kulturowym wizerunku wampira, „Media - Kultura - Komunikacja Społeczna” 2016, t. 12, nr 1.

Davison C.M., Anti-Semitism and British Gothic Literature, New York 2004.

„Dracula”. The Vampire and the Critics, ed. M.L. Carter, Ann Arbor 1988.

Drezner D.W., Theories of International Politics and Zombies, Princeton 2011.

Dybel P., Zagadka ,drugiej ptci”. Spory wokót różnicy seksualnej w psychoanalizie i feminizmie, Kraków 2012.

Eco U., Superman $w$ literaturze masowej. Powieść popularna: między retoryka a ideologia, przeł. J. Ugniewska, Kraków 2008.

Fanu J.S. Le, Carmilla, przeł. M. Kozłowski, Kraków 1974.

Gemra A., Od gotycyzmu do horroru. Wilkołak, wampir i Monstrum Frankensteina w wybranych utworach, Wrocław 2008.

Gemra A., Od zera do bohatera: ewolucja statusu wampira w wybranych utworach [w:] , Homo mythicus " i mityczne wzorce tożsamości, red. H. Kubicka, G. Trębicki, B. Trocha, Zielona Góra 2014.

Gennep A. van, Obrzędy przejścia. Systematyczne studium ceremonii, przeł. B. Biały, Warszawa 2006.

Gielata I., Koziołek R., Coraz piękniejsze potwory, „Świat i Słowo” 2012, nr 1.

Gieysztor A., Mitologia Stowian, Warszawa 1982.

Goethe J.W., Wybór poezji, oprac. Z. Ciechanowska, BN II 48, Wrocław 1968.

Golka M., Socjologia kultury, Warszawa 2007.

Groom N., The Vampire: A New History, New Haven-London 2018.

wampiryzmem ukazuje wielość interpretacji tego zjawiska, zob. M. Wolski, Wrażliwi krwiopijcy.

O wspótczesnych antybohaterach wampirycznych, Kraków 2020. 
Hodgson G., The Myth of American Exceptionalism, New Haven-London 2009.

„Homo mythicus” i mityczne wzorce tożsamości, red. H. Kubicka, G. Trębicki, B. Trocha, Zielona Góra 2014.

Janion M., Odnawianie znaczeń, Kraków 1980.

Janion M., Projekt krytyki fantazmatycznej. Szkice o egzystencjach ludzi i duchów, Warszawa 1991.

Janion M., Reduta. Romantyczna poezja niepodległościowa, Kraków 1979.

Janion M., Wampir. Biografia symboliczna, Gdańsk 2008.

Janion M., Wobec zła, Chotomów 1989.

Kaczor K., Od Draculi do Lestata. Portrety wampira, Gdańsk 1998.

Khader J., Will the Real Robert Neville Please, Come Out? Vampirism, the Ethics of Queer Monstrosity, and Capitalism in Richard Matheson's "I Am Legend"?, „Journal of Homosexuality” 2013, Vol. 60, No. 4.

King S., Danse Macabre, przeł. P. Braiter, P. Ziemkiewicz, Warszawa 2009.

King S., Jak pisać. Pamiętnik rzemieślnika, przeł. P. Braiter, Warszawa 2014.

King S., Miasteczko Salem, przeł. A. Nakoniecznik, Warszawa 2012.

Kita M., Tekstowo zmediatyzowane doświadczenie bycia wampirem. Wokót „Zmierzchu” Stephenie Meyer, ,Język Artystyczny” 2014, t. 15.

Kitliński T., Obcy jest w nas. Kochać wedtug Julii Kristevej, Kraków 2001.

Kletowski P., Nosferatu [w:] K.M. Śmiałkowski, Wampir. Leksykon, Bielsko-Biała 2010.

Kokot J., Pisanie jako modelowanie świata. „Dracula” Brama Stokera, „Przegląd Humanistyczny" 2008, nr 5.

Kolasińska I., Zęby wampira - dyskretny urok pożąania [w:] Niedyskretny urok kiczu. Problemy filmowej kultury popularnej, red. G. Stachówna, Kraków 1997.

Konstantinos, Wampiry wśród nas. Ukryta prawda, przeł. E. Androsiuk-Kotarska, Białystok 2012.

Krajewski M., Kultury kultury popularnej, Poznań 2005.

Kristeva J., Potęga obrzydzenia. Esej o wstręcie, przeł. M. Falski, Kraków 2007.

Krysztofiak M., Dracula Antychryst - wattki religijne w literaturze wampirycznej, „Przegląd Religioznawczy” 2019, nr 4.

Lasoń-Kochańska G., Śmiertelne zaślubiny. Mit i tajemnica w cyklu „Zmierzch” Stephenie Meyer [w:] Mit - literatura - tajemnica, red. W. Gruszczyński, T. Ratajczak, B. Trocha, Zielona Góra 2013.

Leśmian B., Poezje, oprac. J. Trznadel, Warszawa 1994.

Lidston R., Dracula and Salem's Lot: Why the Monsters Won't Die, „West Virginia University Philological Papers" 1982, Vol. 28.

Lindqvist J.A., Wpuść mnie, przeł. E. Frątczak-Nowotny, Warszawa 2008.

Literatura i kultura popularna. Badania i metody, red. A. Gemra, A. Mazurkiewicz, Wrocław 2014.

Łotman J., Minc Z., Literatura i mitologia [w:] Sztuka w świecie znaków, oprac. i przeł. B. Żyłko, Gdańsk 2002.

Łuksza A., Lowelas grobów: wampir na scenie w XIX wieku, „Literatura Ludowa” 2014, $\mathrm{nr} 2$.

Majmurek J., Dekada horroru, „Pismo” 2019, nr 5. 
Marcela M., Monstruarium nowoczesne, Katowice 2015.

Markowski M.P., Nieobliczalne. Eseje, Kraków 2007.

Marks K., Kapitat. Krytyka ekonomii politycznej, t. 1, ks. 1, Proces wytwarzania kapitału, przeł. H. Lauer, M. Kwiatkowski, J. Heryng, L. Selen, Warszawa 2010.

Matheson R., Jestem legenda, przeł. W. Kustra, Katowice 1992.

Mazurkiewicz A., Potomkowie hrabiego Draculi - szkic do portretu (o recepcji motywów wampirycznych we współczesnej literaturze), „Literaturoznawstwo” 2007, nr 1.

Mazurkiewicz F., Męskość dziewiętnastowieczna - prolegomena, „Teksty Drugie” $2015, \mathrm{nr} 2$.

McKee P., Racialization, Capitalism, and Aesthetics in Stoker's “Dracula”, „Novel” 2002, Vol. 36, No. 1.

Meyer S., Zmierzch, przeł. J. Urban, Wrocław 2009.

Mickiewicz A., Dziady, część trzecia, oprac. J. Kallenbach, BN I 20, Kraków 1920.

Miller A., Czarownice z Salem, przeł. A. Bańkowska, Warszawa 2009.

Mit-literatura - tajemnica, red. W. Gruszczyński, T. Ratajczak, B. Trocha, Zielona Góra 2013.

Moszyński K., Kultura ludowa Słowian, t. II, Kultura duchowa, cz. 1, Warszawa 1967.

Mouffe C., Polityczność, przeł. J. Erbel, Warszawa 2008.

Myślicki M., Spójrz w twarz wampira. „True Blood” jako horror zaangażowany w perspektywie teorii inności [w:] Światy grozy, red. K. Olkusz, Kraków 2016.

Nawrocki R., Zmierzch bezpieczeństwa oświeceniowych paradygmatów i jutrzenka stereotypu popkultury: gotycyzm i preromantyzm, „Świat i Słowo” 2013, nr 2.

Niedyskretny urok kiczu. Problemy filmowej kultury popularnej, red. G. Stachówna, Kraków 1997.

Nowe opisanie świata. Literatura $i$ sztuka dla dzieci $i$ młodzieży $w$ kręgach oddziaływań, red. B. Niesporek-Szamburska, M. Wójcik-Dudek, Katowice 2013.

Olkusz K., Rozbieranie wampira. Erotyczne imaginacje i seksualne fantazje w romansach paranormalnych/metafizycznych (na wybranych przykładach), „Orbis Linguarum" 2015, nr 43.

Olkusz K., W objęciach kiczu, czyli co skrywa (lub odsłania) romans paranormalny/ metafizyczny. Na przykładzie cyklu ,Love at Stake” Kerrelyn Sparks [w:] Literatura i kultura popularna. Badania i metody, red. A. Gemra, A. Mazurkiewicz, Wrocław 2014.

Orbitowski Ł., Arcyłotry Ameryki, „Gazeta Wyborcza” 2012, nr 169.

Ostrowska J., ,, Czysta krew”, czyli jak demoniczna mniejszość przejmuje władze! [w:] Seriale. Przewodnik Krytyki Politycznej, Warszawa 2011.

Paszylk B., Leksykon filmowego horroru, Michałów-Grabina 2006.

Petoia E., Wampiry i wilkołaki. Źródła, historia, legendy od antyku do współczesności, przeł. B. Bielańska, J. Kornecka, N. Korzycka, M. Małecka, A. Pers, Kraków 2004.

Piasecki J., Mój nauczyciel jest... wampirem, przeł. C. Frąc, Warszawa 2002.

Ransom A.J., "I Am Legend" as American Myth: Race and Masculinity in the Novel and Its Film Adaptations, Jefferson 2018. 
Reduta. Magnetofonowy zapis dyskusji, która odbyła się 23 lutego 1980 roku w Teatrze ,, Wybrzeże” w Gdańsku po przedstawieniu „Dziadów” Adama Mickiewicza w reżyserii Macieja Prusa, oprac. D. Szkop-Dąbrowska, „Punkt” 1981, nr 13.

Rice A., Wywiad z wampirem, przeł. T. Olszewski, Poznań 2009.

Riess J., Book of Mormon Stories That Steph Meyer Tells to Me: LDS Themes in the Twilight Saga and The Host, „BYU Studies Quarterly” 2019, Vol. 48.

Saja K., Wampir w świecie antropii. Kognitywizm subsymboliczny w literaturoznawstwie, Kraków 2017.

Sanders J.S., Closure and Power in Salem's Lot, „Journal of the Fantastic in the Arts” 1999, Vol. 10.

Seriale. Przewodnik Krytyki Politycznej, Warszawa 2011.

Shapiro S., Transvaal, Transylvania: Dracula's World-system and Gothic periodicity, „Gothic Studies” 2008, Vol. 10, No. 1.

Slany K., Groza w literaturze dziecięcej. Od Grimmów do Gaimana, Kraków 2016.

Stachówna G., Roman Polański i jego filmy, Warszawa 1994.

Stevenson J.A., A Vampire in the Mirror: The Sexuality of “Dracula”, „PMLA” 1988, Vol. 103, No. 2.

Stoker B., Dracula, przeł. M. Król, Kraków 2008.

Sztuka w świecie znaków, oprac. i przeł. B. Żyłko, Gdańsk 2002.

Śmiałkowski K.M., Wampir. Leksykon, Bielsko-Biała 2010.

Światy grozy, red. K. Olkusz, Kraków 2016.

Tałuć K., Horror w tekstach dla młodego odbiorcy (rekonesans badawczy) [w:] Nowe opisanie świata. Literatura i sztuka dla dzieci i młodzieży w kręgach oddziaływań, red. B. Niesporek-Szamburska, M. Wójcik-Dudek, Katowice 2013.

Turner V., Gry społeczne, pola i metafory. Symboliczne działanie w społeczeństwie, przeł. W. Usakiewicz, Kraków 2005.

Wampir jest $w$ każdym z nas. Profesor Maria Janion $w$ rozmowie z Piotrem Najsztubem, „Przekrój” 2003, nr 29.

Welsh R., Wampiurek, przeł. A. Oczko, Warszawa 2005.

Wolski M., Wrażliwi krwiopijcy. O wspótczesnych antybohaterach wampirycznych, Kraków 2020.

Ziębiński R., Stephen King. Instrukcja obstugi, Warszawa 2019.

Zmierzch i filozofia. Wampiry, wegetarianie i pogoń za nieśmiertelnościa, oprac. W. Irwin, J.J. Wisnewski, R. Housel, przeł. A. Krzysztoń, J. Urban, Warszawa 2009.

Zmierzch i historia, red. N. Reagin, przeł. E. Siarkiewicz, P. Żak, Warszawa 2010.

Zurutuza K.P., The Vampire as the Gender and Racial Construction of Western Capitalism's White Masculinity in English and American Gothic Literature, „International Journal of Arts \& Sciences" 2015, Vol. 8.

Zwart H., Vampires, Viruses and Verbalisation: Bram Stoker's Dracula as a genealogical window into fin-de-siècle science, „Janus Head” 2018, Vol. 16.

Zwierzchowski P., Smutek wiecznego życia. Filmowe wyobrażenia mitu o nieśmiertelności, „Kwartalnik Filmowy” 2003, nr 41-42. 


\section{Filmografia}

Czysta krew, reż. A. Ball, USA 2008.

Dracula, reż. F.F. Coppola, USA 1992.

Nieustraszeni pogromcy wampirów albo: Przepraszam, ale pańskie zęby tkwia w mej szyi, reż. R. Polański, USA-Wielka Brytania 1967.

Nosferatu wampir, reż. W. Herzog, Francja-RFN 1979.

Postrach nocy, reż. C. Gillespie, USA 2011.

Postrach nocy, reż. T. Holland, USA 1985.

\section{Źródła internetowe}

Crawford H., The Cultural-Historical Origins of the Literary Vampire in Germany, „Journal of Dracula Studies” 2005, Vol. 7, s. 4-7, https://research.library.kutztown.edu/cgi/viewcontent.cgi? article $=1040 \&$ context=dracula-studies (dostęp: 30.01.2021).

Fetters A., At Its Core, the “Twilight” Saga Is a Story About, „The Atlantic” 2012, Nov. 15, https://www.theatlantic.com/entertainment/archive/2012/11/at-its-corethe-twilight-saga-is-a-story-about/265328/ (dostęp: 9.01.2021). 